\title{
Epiphytic cyanobacterium Gloeotrichia pisum as an indicator of nitrogen depletion
}

\author{
Christiane Hudon $^{1, *}$, Antonella Cattaneo ${ }^{2}$, Pierre Gagnon $^{1}$ \\ ${ }^{1}$ Fluvial Ecosystem Research Section, Water Sciences and Technology Directorate, Environment Canada, 105 McGill St., \\ Montreal, Quebec H2Y 2E7, Canada \\ ${ }^{2}$ Département de Sciences Biologiques, Université de Montréal, PO Box 6128, Succ. A., Montréal, Québec H3C 3J7, Canada
}

\begin{abstract}
The epiphytic cyanobacterium Gloeotrichia pisum forms spherical colonies embedded in a gelatinous matrix that is attached to submerged aquatic vegetation. In surveys of 2 fluvial lakes of the St. Lawrence River conducted in 2006-2007, we examined its growth conditions and diazotrophic ability in conjunction with the biomass and condition (carbon $(\mathrm{C})$, nitrogen $(\mathrm{N})$, phosphorus (P) and chl a content) of its supporting macrophyte, Vallisneria americana. G. pisum occurred in nearshore areas, in sheltered embayments characterized by clear waters with low dissolved inorganic nitrogen (DIN) $\left(\mathrm{NO}_{2}-\mathrm{NO}_{3}<35 \mu \mathrm{g} \mathrm{N} \mathrm{l}^{-1}, \mathrm{NH}_{4}<7 \mu \mathrm{g} \mathrm{N} \mathrm{l} \mathrm{N}^{-1}\right.$ ) and total dissolved phosphorus $\left(<20 \mu \mathrm{g} \mathrm{P}^{-1}\right)$ concentrations. Low water levels, warm temperatures and sunny conditions in 2007 resulted in early colonization, sustained low DIN concentrations and a 4-fold rise in G. pisum biomass compared to 2006. At all sites, the near-zero stable nitrogen isotope $\left(\delta^{15} \mathrm{~N}\right)$ signature of G. pisum revealed its exclusive reliance on atmospheric nitrogen. $V$. americana leaves that were heavily colonized by G. pisum exhibited significantly lower chl $a_{1} \% \mathrm{~N}$ and \% $\mathrm{P}$ contents than those at sites where $G$. pisum was absent. The poor condition of $V$. americana was more likely related to low DIN concentration than to any direct effect of cyanobacterial colonization. G. pisum thus integrates complex, temporally variable water-quality characteristics that are dependent upon hydrology and water residence time, thus acting as an early warning indicator of incipient habitat degradation that may lead to cyanobacterial proliferation and low biomass of vascular macrophytes.
\end{abstract}

KEY WORDS: Nitrogen depletion · Phosphorus · Wetlands · Vallisneria americana · Benthic cyanobacteria · Gloeotrichia pisum

\section{INTRODUCTION}

Freshwater ecosystems worldwide are increasingly faced with nutrient overload from urban and agricultural activities, resulting in the noxious proliferation of phytoplankton and macrophytes. Excessive phosphorus (P) loads have been consistently identified as the main cause of eutrophication in fresh waters (Vollenweider 1968, Schindler 1974), in contrast to estuaries and marine waters, where nitrogen $(\mathrm{N})$ is usually limiting (see review of Howarth \& Marino 2006). Despite increasing eutrophication, episodes of dissolved inorganic nitrogen (DIN) depletion have been reported in lakes, rivers and wetlands (Scott et al. 2005, Weyhenmeyer et al. 2007, Lewis \& Wurtsbaugh 2008). Exces- sive P fertilization has been shown to lead to severe $\mathrm{N}$ limitation in freshwater phytoplankton, favouring the dominance of $\mathrm{N}$-fixing cyanobacteria (Hyenstrand et al. 1998, Schindler et al. 2008).

Factors inducing the dominance of benthic cyanobacteria in running waters are less documented (Vis et al. 2008). We studied the epiphytic cyanobacterium Gloeotrichia pisum, which forms spherical colonies embedded in a gelatinous matrix that is attached to submerged aquatic vegetation (Granetti 1969, Aziz \& Whitton 1988). G. pisum is morphologically similar to the better-studied $G$. echinulata, which is a taxon that exhibits a planktonic phase after its initial development in shallow littoral sediments (Roelofs \& Oglesby 1970, Carey et al. 2008). The widespread occurrence of 
G. pisum in the St. Lawrence River coincided with latesummer depletion of DIN in an area located downstream of a dense wetland through which water percolated slowly (Vis et al. 2008). These observations led us to hypothesize that the occurrence of this species could reflect the overall hydrological and chemical conditions prevailing during the entire growing season, thus integrating seasonal variations in water chemistry in rivers and reservoirs, where water quality changes quickly with discharge (Chêtelat \& Pick 2001, Hudon \& Carignan 2008). The testing of this hypothesis further provided an opportunity to investigate the effects of persistent low DIN concentrations and of G. pisum presence on submerged macrophytes.

To this end, we assessed the distribution and abundance of Gloeotrichia pisum that are attached to the macrophyte Vallisneria americana in surveys of 2 fluvial lakes of the St. Lawrence River, both of which are characterized by spatially and temporally variable water masses. Concomitantly, we measured $V$. americana biomass, condition ( $\mathrm{C}, \mathrm{N}, \mathrm{P}$ and chlorophyll content) and epiphytic cover to determine whether or not reduced DIN concentrations, as indicated by G. pisum, were affecting the aquatic vegetation.

\section{MATERIALS AND METHODS}

Study site. The study was carried out in 2 fluvial lakes of the St. Lawrence River-Lake Saint-Louis $\left(45.40^{\circ} \mathrm{N}, 73.80^{\circ} \mathrm{W}\right)$ and Lake Saint-Pierre $\left(46.20^{\circ} \mathrm{N}\right.$, $72.85^{\circ} \mathrm{W}$ ) (Fig. 1) - located respectively $30 \mathrm{~km}$ upstream and $85 \mathrm{~km}$ downstream of Montreal, Quebec, Canada. Fluvial lakes formed by the widening of the main river stem are relatively slow-flowing $\left(<0.5 \mathrm{~m} \mathrm{~s}^{-1}\right)$ and shallow (mean depth $\sim 3 \mathrm{~m}$ ), with the exception of a man-made central navigation channel (depth $>11 \mathrm{~m}$ ) that concentrates a significant portion of the river flow.

In Lake Saint-Louis, clear waters originating from Lake Ontario are characterized by low total dissolved $\mathrm{P}$ (TDP $<8 \mu \mathrm{g} \mathrm{P}^{-1}$ ) and medium DIN ( $>350 \mu \mathrm{g} \mathrm{N} \mathrm{l}^{-1}$ ) concentrations; these waters flow in the central navigation channel and spill over to the south shore. In contrast, turbid, $\mathrm{P}$ enriched (TDP > $10 \mu \mathrm{g} \mathrm{P} \mathrm{l}^{-1}$ ), low DIN

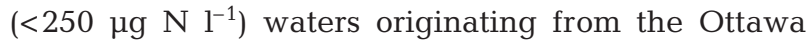
River flow along the north shore. In Lake Saint-Pierre, the water mass originating from Lake Ontario occupies the central, fast-flowing navigation channel, whereas slow-flowing areas along the north and south shores are largely under the influence of the Ottawa River and other nutrient-rich tributaries (Hudon \& Carignan 2008).

The shallow depth, gentle slope, slow current, and high nutrient content that prevail in the fluvial lakes of the St. Lawrence River favour the development of large beds of submerged aquatic vegetation. This vegetation is heavily colonized by periphyton and filamentous green algae, which tend to proliferate during summers of low discharge (Vis et al. 2007).

Sampling and analyses. The spatial distribution and abundance of Gloeotrichia pisum at the end of the growing season (late August) was assessed in both Lakes Saint-Louis (2007 only) and Saint-Pierre (2006-2007) (Table 1). Seasonal (May to October) and interannual changes in abundance were monitored at a subset of stations along the south shore of Lake Saint-Pierre (Table 1).

Environmental variables (weather conditions, water level, physical and chemical water quality, plant biomass) were measured simultaneously at each station. Daily insolation (number of hours of sunshine) and air temperature data at Montreal Pierre Trudeau Airport in 2006-2007 were obtained from Environment Canada (2007). Daily water levels for 2006-2007 were obtained for Lake Saint-Pierre (at Courbe No. 2, Station 17975, 3.383 m IGLD85 [International Great Lakes Datum of 1985]) (DFO 2007).

We measured water temperature and conductivity using a conductivity meter (model 600XLM, YSI). Underwater light extinction coefficient $(\mathrm{K})$ was either measured with a light meter (LI-COR Biosciences) or calculated from previously documented relationships that were derived from suspended particulate matter (SPM) and dissolved organic carbon (DOC) concentrations.

Water samples were collected just below the surface. Given the absence of vertical stratification in the fluvial lakes, these samples were considered representative of the entire water column (C. Hudon unpubl. data). Unfiltered subsamples were used for the analyses of SPM (APHA 1995), total P (TP), and total $\mathrm{N}$ (TN). Filtered (Whatman GF/C) water was used for the analyses of TDP, $\mathrm{NO}_{2}{ }^{-}+\mathrm{NO}_{3}{ }^{-}, \mathrm{NH}_{4}{ }^{+}, \mathrm{DOC}$, and colour (platinum/cobalt, Pt/Co method) (Environment Canada 2005).

The biomasses of vascular macrophytes (i.e. Vallisneria americana), filamentous chlorophytes (i.e. Cladophora, Oedogonium, Hydrodictyon) and benthic cyanobacteria (i.e. Lyngbya wollei) were estimated at each site from 3 to 10 samples collected using a double-headed rake (35 $\mathrm{cm}$ wide) (Yin et al. 2000) that was dragged over a length of $\sim 1 \mathrm{~m}\left(0.35 \mathrm{~m}^{2}\right)$. The sampled vegetation was thoroughly rinsed, sorted among major plant types (vascular plants, filamentous chlorophytes and benthic cyanobacteria) and weighed wet (to the nearest $0.01 \mathrm{~kg}$ ) on board the boat. Previously documented wet to dry mass (DM) conversion factors (Hudon \& Lalonde 1998) were used to estimate vegetation $\mathrm{DM} \mathrm{m}^{-2}$.

Although Gloeotrichia pisum colonizes all submerged aquatic vegetation, we focused our assessment 


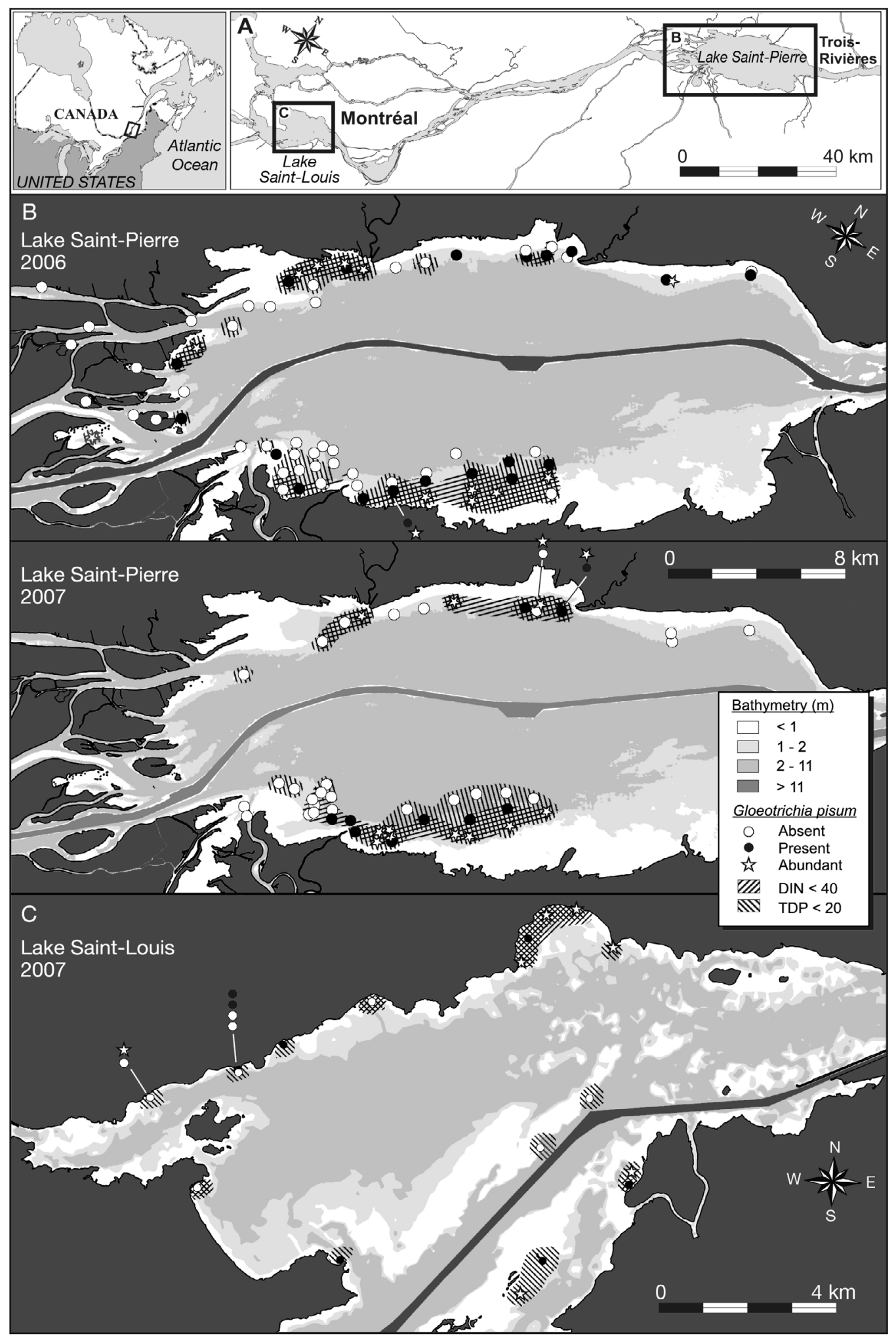

Fig. 1. (A,B,C) Two fluvial lakes of the St. Lawrence River (Québec). Location of stations where Gloeotrichia pisum was absent $(\mathrm{O})$, present (O) and abundant (冬) during the late-August surveys carried out in (B) Lake Saint-Pierre $\left(46.20^{\circ} \mathrm{N}, 72.85^{\circ} \mathrm{W}\right.$ in 2006 and 2007, and (C) Lake Saint-Louis $\left(45.40^{\circ} \mathrm{N}, 73.80^{\circ} \mathrm{W}\right)$ in 2007 are presented. In B and C, bathymetry and areas of low dissolved

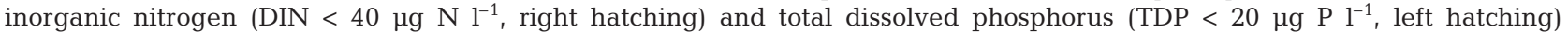


Table 1. Spatial and temporal surveys carried out in Lake Saint-Pierre (LSP) and Lake Saint-Louis (LSL) to study the distribution of the epiphytic cyanobacterium Gloeotrichia pisum

\begin{tabular}{|llcc|}
\hline Lake & Date & \# of stations & Type \\
\hline LSP & 29-31 August 2006 & 68 & Spatial \\
LSP & 28 - 30 August 2007 & 48 & Spatial \\
LSL & 5 September 2007 & 18 & Spatial \\
LSP & 29 June - 16 October 2006 & $3-11$ (south shore) & Temporal \\
LSP & 2 May - 10 October 2007 & $2-9$ (south shore) & Temporal \\
\hline
\end{tabular}

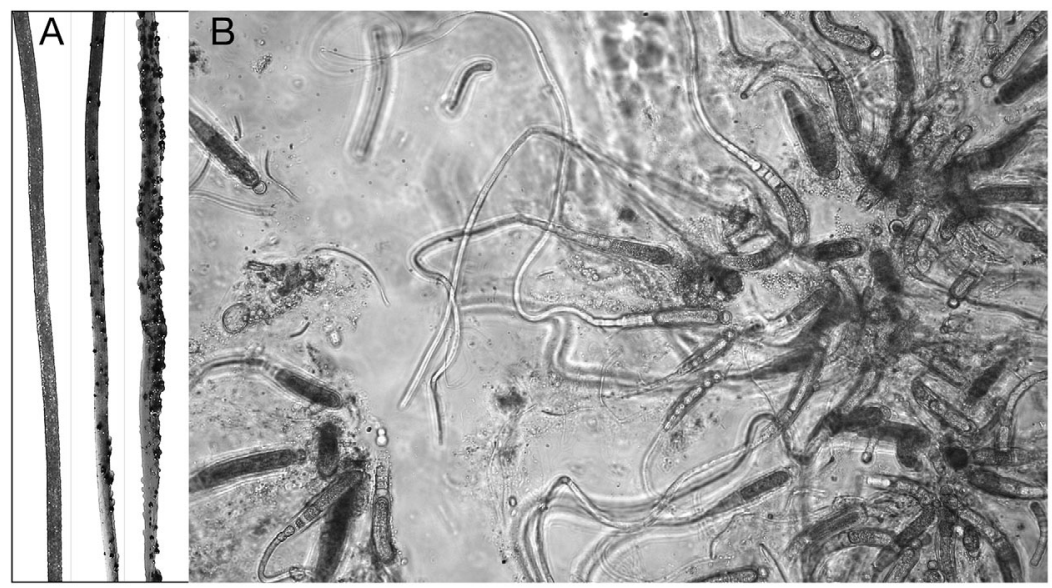

Fig. 2. Gloeotrichia pisum. (A) Colonies on Vallisneria americana leaves $(1 \mathrm{~cm}$ width) showing abundance classes (from left to right: absent, present, abundant); (B) details of a colony showing heterocysts. Diameter of heterocyst $=$ $8 \mu \mathrm{m}$, magnification $400 \times$

on Vallisneria americana, which is the most common vascular plant species in the St. Lawrence River (Vis et al. 2007) and whose linear, ribbon-like leaves greatly simplified the quantification of epiphytes. In the field, the relative abundance of $G$. pisum on $V$. americana was visually ranked (absent: 0, present: 1 and abundant: 2) at each station (Fig. 2). Field rankings were verified against laboratory measurements of $G$. pisum biomass on $V$. americana leaves (mg G. pisum DM g ${ }^{-1}$ $V$. americana DM) that were derived from a composite sample of $V$. americana leaves collected at each site and frozen until analysis. We quantified G. pisum colonies (number, volume, DM), biomass of other epiphytes ( $\mathrm{chl} a$ ), and indicators of $V$. americana condition ( $\% \mathrm{C}, \% \mathrm{~N}, \% \mathrm{P}$ and chl a tissue contents). All epiphytes, including $G$. pisum colonies, were manually removed from $10 \mathrm{~V}$. americana leaves, which were subsequently dried $\left(60^{\circ} \mathrm{C}\right)$ and weighed (to the nearest $\left.0.1 \mathrm{mg}\right)$. G. pisum colonies were sorted from micro-epiphytes under a dissecting microscope, measured (to the nearest $0.01 \mathrm{~mm}$ ), dried and weighed (to the nearest $0.001 \mathrm{mg})$ to assess their total volume $\left(\mu \mathrm{m}^{3}\right.$, derived from individual measurements of colonies) and DM (mg g ${ }^{-1}$ V. americana DM).
The chl a content was determined separately for cleaned Vallisneria americana leaves and for their loosely attached micro-epiphytes ( $\mu \mathrm{g}$ chl a $\mathrm{mg}^{-1}$ V. americana DM), using spectrophotometry after cold ethanol extraction (Nusch 1980). C and N contents of powdered $V$. americana leaves were measured with a Perkin Elmer 2400 Elemental Analyser (Environment Canada 2005). $\mathrm{P}$ content of $V$. americana tissues was determined following Stainton et al. (1977).

Stable isotope analysis. Plant tissues were oven dried $\left(60^{\circ} \mathrm{C}\right)$, exposed to concentrated $\mathrm{HCl}$ fumes for $24 \mathrm{~h}$ and pulverized. The stable isotopic composition of weighted amounts of powdered samples was determined using isotope ratio mass spectrometry (Conflo II and DeltaPlus XP IRMS, ThermoFinnigan). The data were normalized using internal standards previously calibrated with international standards IAEA-CH-6, IAEA-NBS22, IAEA-N1, IAEA-N2, USGS-40, USGS41 ; analytical precision was $0.2 \%$ (2 SD; Hatch Laboratory, University of Ottawa, Canada).

Data analysis. The biomass of Gloeotrichia pisum (mg DM g ${ }^{-1}$ Vallisneria americana DM) was allocated to 1 of 3 groups: absent (biomass $=0$ ), present, and abundant (biomass $<25$ and $\geq 25 \mathrm{mg} \mathrm{DM} \mathrm{g}{ }^{-1} V$. americana DM, respectively). The accuracy of our field ranking of $G$. pisum was then assessed against laboratory measurements and the agreement between them beyond chance alone was quantified with Cohen's kappa (PROC FREQ, SAS V. 9.1). The spatial distribution of G. pisum abundance and the various water quality characteristics at each station were mapped (MapInfo V. 6.5); the relationships between $G$. pisum abundance and the physical, chemical and biological variables measured at each station were detected using simple correlations (Pearson r).

The physical, chemical and biological variables (some of which were heteroscedastic) corresponding to each abundance class of Gloeotrichia pisum were compared using Kruskal-Wallis nonparametric ANOVA followed by a comparison of mean ranks (Statistix analytical software). Interannual (2006-2007) differences in biomass, condition and elemental plant composition at the same 25 sites, on the same calendar dates (30 August 2006 and 2007), were assessed using 2-tailed paired $t$-tests (Microsoft Office Excel). Meteorological, 
water-level and physical-chemical conditions prevailing in 2006 and 2007 were contrasted using 1-tailed paired $t$-tests (Microsoft Office Excel). In the latter case, 1-tailed tests were selected because we hypothesized that conditions favourable to G. pisum (warmer, more transparent water and more intense DIN depletion) had prevailed under the warm, sunny, dry and low water level conditions experienced during summer 2007.

The presence and abundance of Gloeotrichia pisum were modeled in 2 steps. First, the probability of occurrence of G. pisum as a function of environmental variables (water depth, transparency, conductivity, colour, current speed, fetch, SPM, DOC and concentration of nutrients) was determined from a logistic regression model (PROC LOGISTIC, SAS V. 9.1). This model was validated using an independent set of 48 observations collected in Lake Saint-Pierre on other dates for which the same variables were measured, by comparing the predicted with the observed occurrence of G. pisum. Second, when $G$. pisum was present, its abundance was related to physical and chemical variables by multiple regressions (PROC REG, SAS V. 9.1).

The relative magnitude of the effects of physical and chemical water characteristics (transparency, nutrient concentrations) and of the biomass of Gloeotrichia pisum on Vallisneria americana condition $(\% \mathrm{~N}$ in tissues) was determined using partial multiple correlations (PROC CANCORR, SAS V. 9.1). This analysis quantifies the strength of the relationship between $V$. americana's condition and each group of variables after accounting for the effect of a second group.

\section{RESULTS}

\section{Characteristics of $G$. pisum and $V$. americana}

Gloeotrichia pisum colonies varied from being spherical to elliptical in form and ranged from 0.3 to $3.6 \mathrm{~mm}$ in diameter (Table 2). Filaments radiated from the centre of the gelatinous colony, tapering from a basal heterocyst to a very fine point (Fig. 2). Colony volume ranged from 0.001 to $14.2 \mathrm{~mm}^{3}$ in 2006; colonies up to $1 \mathrm{~cm}$ across were observed (but not systematically measured) in 2007. The different estimates of abundance (no. of colonies, volume and dry mass) of G. pisum on Vallisneria americana leaves were highly correlated to each other: number of colonies was closely correlated to volume $\left(\mathrm{mm}^{3} ; \mathrm{r}=0.92, \mathrm{p}<0.001\right.$,
$\mathrm{N}=36$ ) and DM (mg; $\mathrm{r}=0.97, \mathrm{p}<0.001, \mathrm{~N}=36)$. DM increased linearly with colony volume after both variables were log-transformed (Table 2). The biomass of G. pisum on $V$. americana reached as high as $770 \mathrm{mg}$ $\mathrm{g}^{-1} V$. americana DM; the biomass of vascular macrophytes in the St. Lawrence River averaged $54 \mathrm{~g}$ DM $\mathrm{m}^{-2}$, reaching up to $554 \mathrm{~g} \mathrm{DM} \mathrm{m}^{-2}$ in the most dense assemblages.

Visual field rankings of the abundance of G. pisum (from 0 (absent) to 2 (abundant)) agreed with their laboratory rankings based on biomass for $75 \%$ of the samples $(\mathrm{N}=134$, kappa $=0.62, \mathrm{SD}=0.05)$, which represents a correspondence higher than would be expected by chance alone.

\section{Spatial distribution of G. pisum and environmental variables}

Sites where Gloeotrichia pisum occurred differed markedly in most physical and chemical variables (Kruskal-Wallis ANOVA; Fig. 3) from those where it was absent. In both fluvial lakes and for both years surveyed, G. pisum occurred at stations located near the shore, in sheltered embayments (Fig. 1) characterized by clear $\left(\mathrm{K}<2 \mathrm{~m}^{-1}, \mathrm{SPM}<5 \mathrm{mg} \mathrm{l}^{-1}\right.$ ) (Fig. 3), slightly coloured $(<37 \mathrm{Pt} / \mathrm{Co}$ colour units) waters. High biomasses of G. pisum also coincided with significantly lower DIN concentrations $\left(\mathrm{NO}_{2}-\mathrm{NO}_{3}<35 \mu \mathrm{g} \mathrm{N}{ }^{-1}\right.$, $\left.\mathrm{NH}_{4}<7 \mu \mathrm{g} \mathrm{N}^{-1}\right)$ and reduced TDP $\left(<20 \mu \mathrm{g} \mathrm{P} \mathrm{l}^{-1}\right)$ than at sites where it was absent. Differences in TN and TP concentrations were mostly explained by their dissolved components (Fig. 3). Consequently, the mean $( \pm$ SD) DIN:TDP molar ratio in water shifted from 13.5 $( \pm 10.4)$ at sites where G. pisum was absent to $2.9( \pm 5.8)$ at sites where it was abundant.

Gloeotrichia pisum distribution at a finer spatial scale was examined by considering a subset of sites 


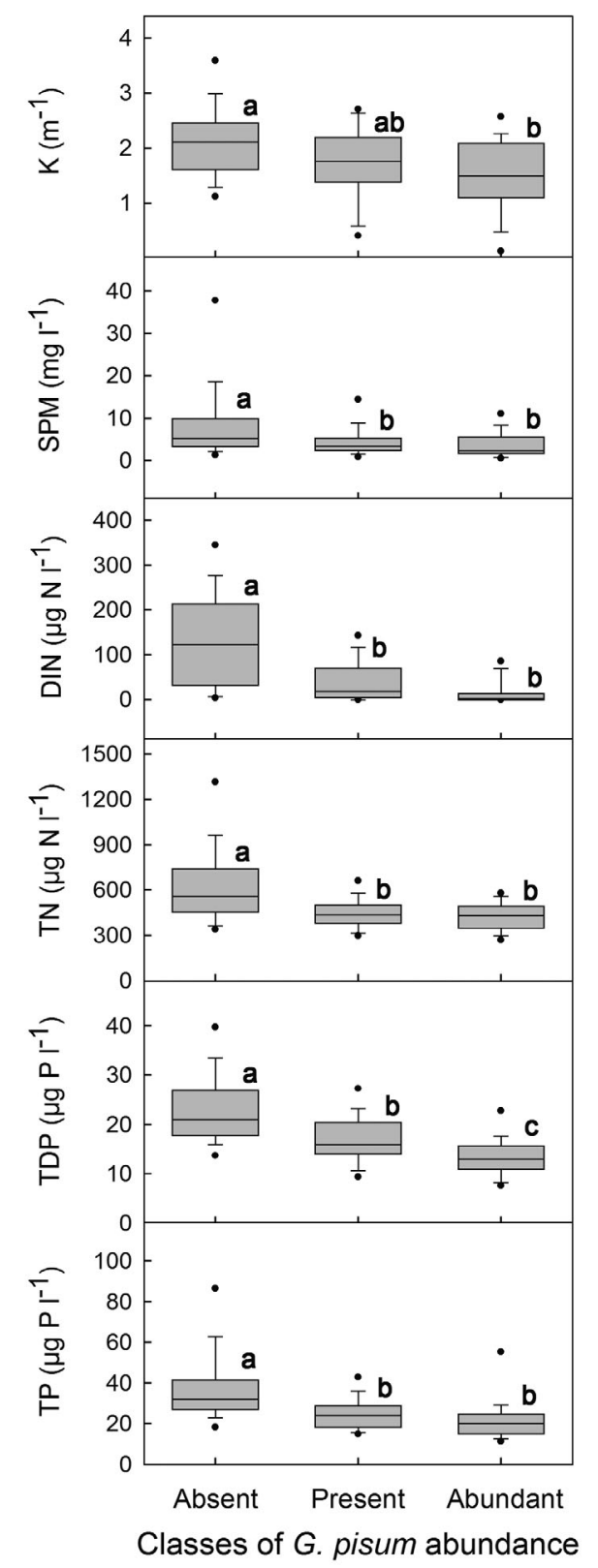

Fig. 3. Physical and chemical characteristics of water at stations where Gloeotrichia pisum colonies were absent $(\mathrm{N}=54)$, present $\left(<25 \mathrm{mg} \mathrm{g}^{-1} \mathrm{DM}\right.$ of Vallisneria americana, $\left.\mathrm{N}=36\right)$, or abundant ( $\geq 25 \mathrm{mg} \mathrm{g}^{-1} \mathrm{DM}$ of $V$. americana, $\mathrm{N}=32$ ), from surveys carried out in lakes Saint-Pierre (2006-2007) and SaintLouis (2007). For each variable, the probability (p) of significant difference between classes is as follows: light extinction coefficient $(\mathrm{K}, \mathrm{p}=0.0003)$, suspended particulate matter $(\mathrm{SPM}, \mathrm{p}=0.0003)$, dissolved inorganic nitrogen (DIN, $\mathrm{p}<$ 0.00001), total nitrogen (TN, p < 0.00001), total dissolved phosphorus (TDP, $\mathrm{p}<0.00001$ ) and total phosphorus (TP, $\mathrm{p}<$ 0.00001); abundance groups for which means differ significantly are identified by different letters (Kruskal-Wallis ANOVA rank test). For each box plot, the boundary of the box indicates the 25th and 75th percentiles, the line within the box marks the median, whiskers above and below the box indicate the 10th and 90th percentiles and dots indicate the 5 th and 95th percentiles that were closely located within the same water mass along the south shore of Lake Saint-Pierre. In both years of study, G. pisum abundance rose with increasing distance downstream, in conjunction with a sharp drop in DIN and a lesser decrease in TDP concentration (Fig. 4).

\section{Modeling the occurrence and biomass of $G$. pisum}

The probability of occurrence of Gloeotrichia pisum was expressed by the logistical relationship:

$$
\operatorname{Prob}_{\mathrm{p}}=1 /\left(1+\mathrm{e}^{-F_{d}}\right)
$$

where (SE in brackets) $F_{d}=4.77(1.00)-0.181(0.050)$ TDP - 0.0193 (0.005) DIN

Rescaled $\mathrm{R}^{2}=0.58$

Applying the parameters estimated in Eq. (1) correctly predicted the presence or absence of $G$. pisum in $80 \%$ of cases in the training data set ( $\mathrm{N}=122$; Fig. $5 \mathrm{~A})$. Validation using independent data revealed that the model yielded accurate predictions of G. pisum presence or absence in $75 \%$ of the cases (Fig. $5 \mathrm{~B} ; \mathrm{N}=48$ ).

When Gloeotrichia pisum was present, its log-transformed biomass was related to DIN and TDP concentrations by a linear model (Eq. 2) that also included water depth $(Z)$ and $\mathrm{TN}\left(\mathrm{p}<0.0001\right.$, adjusted $\mathrm{R}^{2}=$ $0.34)$ :

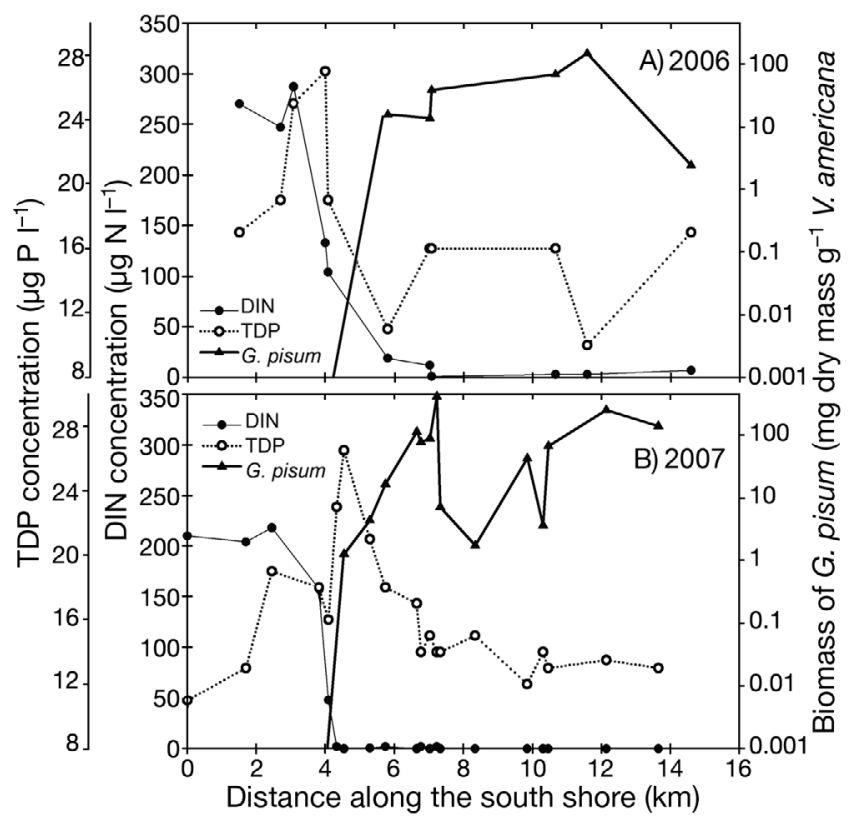

Fig. 4. Spatial gradient of Gloeotrichia pisum abundance and concentrations of dissolved inorganic nitrogen (DIN) and total dissolved phosphorus (TDP) with distance along the south shore of Lake Saint-Pierre in (A) 2006 and (B) 2007. Sites located within the same water mass were identified based on conductivity values 


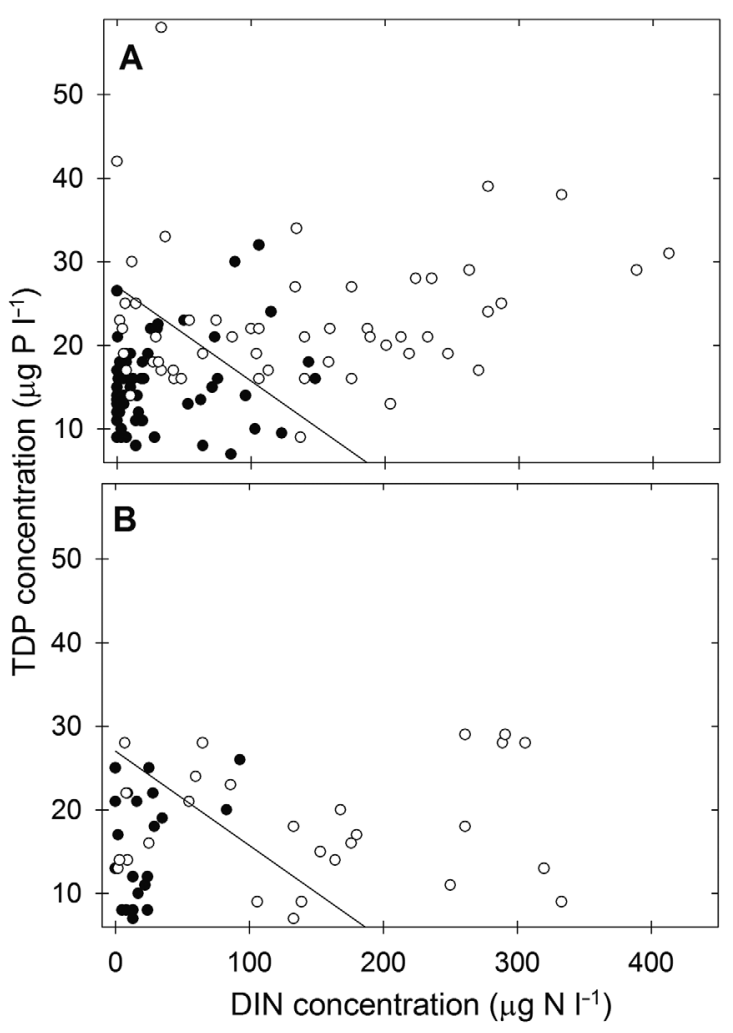

Fig. 5. (A) Performance (data from spatial surveys in Lake Saint-Pierre and Lake Saint-Louis on 30 August 2006 and 2007, $N=122$ ) and (B) validation (data from other surveys in Lake Saint-Pierre in August and September 2006-2007, N = 48 ) of the model predicting the probability of occurrence ( or absence (O) of Gloeotrichia pisum from the combination of dissolved inorganic nitrogen (DIN) and total dissolved phosphorus (TDP) concentrations. ——: Boundary line indicating $50 \%$ probability of occurrence $\log _{10}($ Biomass $)=a+b \mathrm{DIN}+c \mathrm{TDP}+d \mathrm{Z}+e \mathrm{TN}$

where the values of estimated parameters $( \pm \mathrm{SE})$ are: $a=9.89 \pm 1.6, b=-0.017 \pm 0.006, c=-0.11 \pm 0.04, d=$ $-1.96 \pm 0.65$ and $e=-0.0067 \pm 0.0027$. The low explanatory power of this relationship, however, limits its use for the actual prediction of the biomass of G. pisum.

\section{Seasonal and interannual variations}

In the St. Lawrence River, Gloeotrichia pisum was typically observed in August and September (Fig. 6A), coinciding with maximum summer temperatures $\left(\geq 25^{\circ} \mathrm{C}\right)$, and remained commonplace $(>40 \%$ of stations) until mid-October, when water temperatures dropped to $\leq 10^{\circ} \mathrm{C}$. In 2006, G. pisum was first detected on 20 August, after its absence had been documented on 3 previous occasions, whereas it first appeared on 27 July 2007, after 2 earlier negative surveys. Once observed, its frequency of occurrence exhibited no clear seasonal pattern (Fig. 6A).

Seasonal sampling along the south shore of Lake Saint-Pierre, where Gloeotrichia pisum was most frequently observed (Fig. 1), showed that DIN concentrations followed a marked seasonal pattern of higher (100 to $400 \mu \mathrm{g} \mathrm{N} \mathrm{l}^{-1}$ ) spring and fall values and lower $\left(<50 \mu \mathrm{g} \mathrm{N} \mathrm{l}^{-1}\right.$ ) summer concentrations (Fig. 6B). The occurrence of $G$. pisum was first recorded 28 and $25 \mathrm{~d}$ after measuring DIN concentrations that were $<100 \mu \mathrm{g}$ $\mathrm{N}^{-1}$ in 2006 and 2007, respectively. The onset of reduced DIN concentrations appeared to coincide with
Fig. 6. Seasonal variations in (A) the proportion of stations where Gloeotrichia pisum was observed in 2006 and 2007 (bars) in Lake Saint-Pierre and cumulative hours of sunshine (dashed lines), and in (B) dissolved inorganic nitrogen (DIN, circles) concentrations and daily water-level (International Great Lakes Datum of 1985, lines) variations. The period elapsed (arrows) between the onset of low DIN concentration and the date of first observation (see panel A and vertical bars on panel B) of $G$. pisum in Lake Saint-Pierre in 2006 (grey bar) and 2007 (black bar) is also indicated

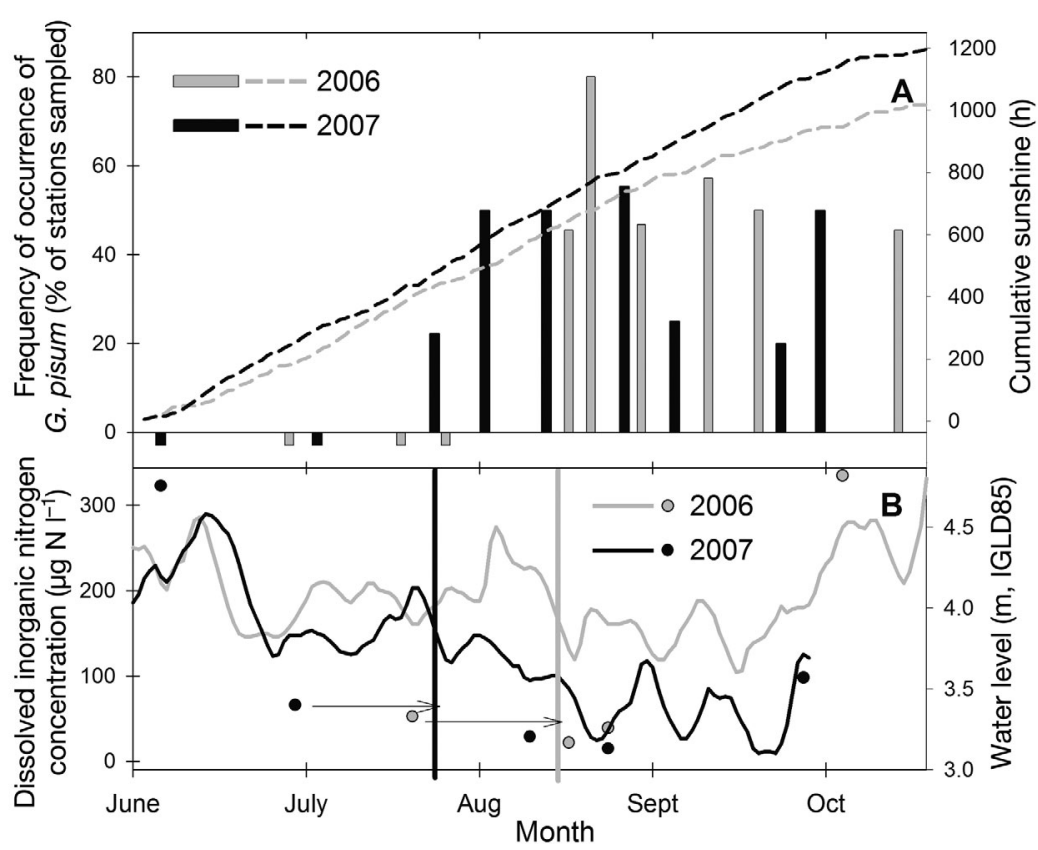


the timing and severity of low water levels in the early part of the growing season (Fig. 6B). The months of June and July of 2007 were characterized by warmer air temperatures (up by $0.9^{\circ} \mathrm{C}, \mathrm{p}=0.06$ ), more sunshine (up by $1.3 \mathrm{~h} \mathrm{~d}^{-1}, \mathrm{p}=0.08$ ) and lower water levels (down by $9 \mathrm{~cm}, \mathrm{p}=0.003$ ) than in the corresponding period in 2006 (1-tailed paired $t$-tests, $\mathrm{N}=61$ ).

The effects of unusually low water levels recorded in late summer 2007 were highlighted by repeated sampling of the same 25 stations in Lake Saint-Pierre on the same date (30 August) in 2006 and 2007. Coinciding with the lower daily water level in 2007 (drop of $37 \mathrm{~cm}$ ), mean water colour decreased from 56 to $30 \mathrm{Pt} / \mathrm{Co}$ colour units $(\mathrm{p}<0.0001,1$-tailed paired $t$ test) and the mean proportion of incident light reaching the bottom rose from 8 to $22 \%(p<0.0001)$. Mean

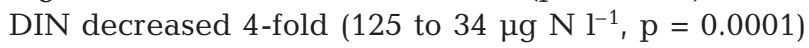
and mean TDP showed a small but significant $(\mathrm{p}=$

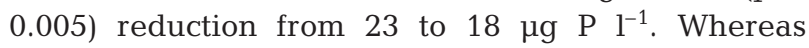
mean macrophyte biomass dropped slightly in 2007 (from 72 to $51 \mathrm{~g} \mathrm{DM} \mathrm{m}^{-2}, \mathrm{p}=0.05$ ) at these same 25 stations, mean biomass of Gloeotrichia pisum rose 4fold (from 12 to $51 \mathrm{mg} \mathrm{g}^{-1}$ Vallisneria americana DM, $\mathrm{p}=0.03$ ). Comparison of the same 25 stations in Lake Saint-Pierre in 2006 and 2007 revealed declines in the mean percentage of $\mathrm{N}$ (from 3.5 to $2.7 \%, \mathrm{p}<$ 0.0001 ) and $\mathrm{C}$ (from 38.7 to $38.0 \%, \mathrm{p}=0.03$ ) in $V$. americana tissues in 2007, while $\% \mathrm{P}(0.16 \%, \mathrm{p}=$ 0.20 ) remained unchanged.

\section{Response of other primary producers growing alongside $G$. pisum}

The high biomass of Gloeotrichia pisum coincided with a low biomass of both macrophytes $(p=0.0015)$ and filamentous chlorophytes (nonsignificant, $\mathrm{p}=$ 0.49 ), and a high biomass of the filamentous benthic cyanobacterium Lyngbya wollei $(\mathrm{p}=0.0014$ ) (KruskalWallis ANOVA) (Fig. 7) over both years and lakes. In addition, at stations where vascular macrophytes were heavily colonized by G. pisum, Vallisneria americana leaves exhibited a decrease in chl a $(\mathrm{p}=$ 0.0008), and epiphytic biomass (as chl a) also dropped (albeit not significantly, $\mathrm{p}=0.08$ ) (Fig. 7). The $\% \mathrm{~N}$ in $V$. americana tissues decreased significantly from 3.2 to $2.2 \%$ (median values) when colonized by G. pisum. A similar decrease was observed for $\% \mathrm{P}$ (from 0.18 to $0.12 \%$ ), whereas $\% \mathrm{C}$ remained unchanged at $\sim 38 \%$ (Fig. 8).

Where they co-occurred, Gloeotrichia pisum tissues comprised twice as much $\mathrm{N}(4.8 \pm 1.0 \% \mathrm{SD}, \mathrm{N}=10)$ as did the Vallisneria americana tissues $(2.2 \pm 0.3 \%, \mathrm{~N}=$ 10) (Fig. 8). Neither the $P$ nor the $C$ content differed between the cyanobacterial epiphyte and its macro-
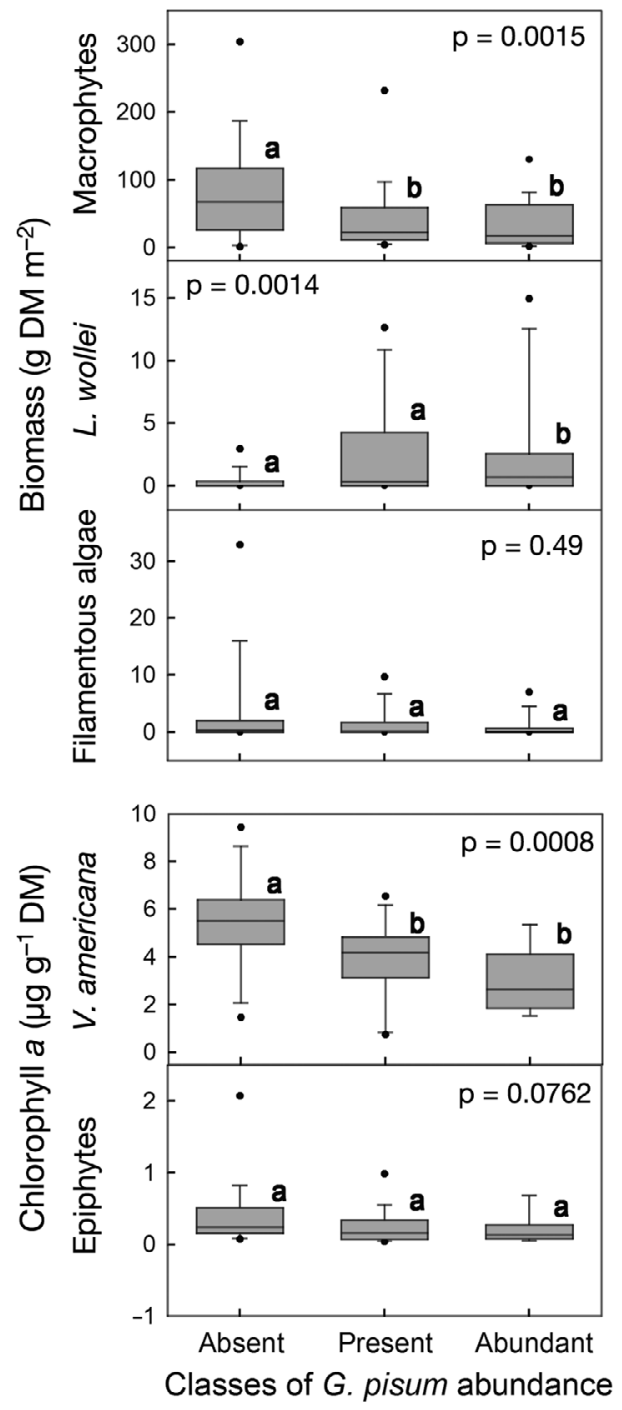

Fig. 7. Biomass of primary producers and condition of Vallisneria americana found at stations where Gloeotrichia pisum was absent, present $\left(<25 \mathrm{mg} \mathrm{DM} \mathrm{g}{ }^{-1} V\right.$. americana DM) or abundant ( $\geq 25 \mathrm{mg} \mathrm{DM} \mathrm{g}^{-1} V$. americana DM). For each variable, the probability (p) of significant differences between classes of abundance is indicated; abundance groups for which means differ significantly are identified by different letters (Kruskal-Wallis ANOVA rank test). For each box plot, the boundary of the box indicates the 25th and 75th percentiles, the line within the box marks the median, whiskers above and below the box indicate the 10th and 90th percentiles and dots indicate the 5th and 95th percentiles. DM: dry matter

phytic substratum. However, V. americana tissues at sites free of G. pisum exhibited higher \%P and \%N than at sites where the macrophyte leaves were colonized (Fig. 8).

We further investigated whether the $\% \mathrm{~N}$ in Vallisneria americana was more strongly linked to water chemistry or to the biomass of Gloeotrichia pisum. Once the 


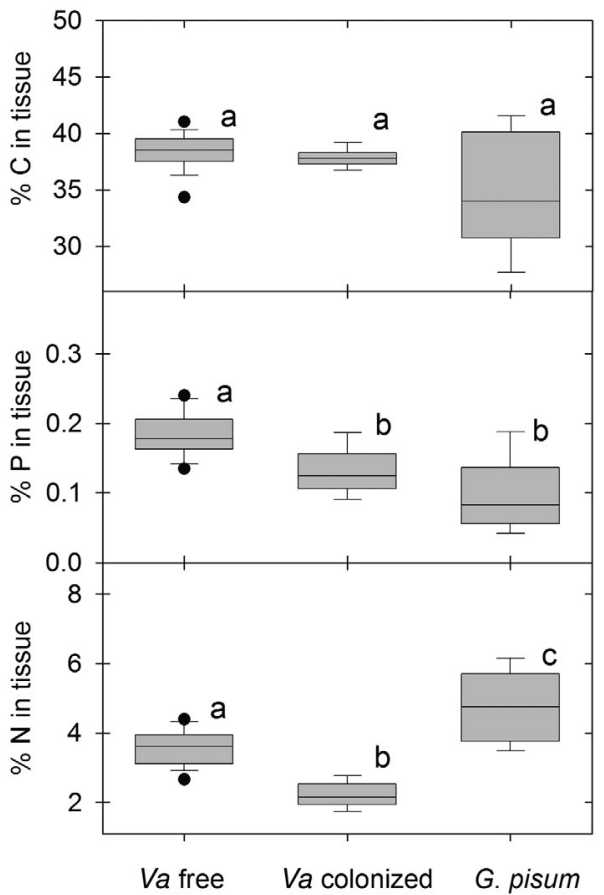

Fig. 8. Comparison of $\% \mathrm{C}, \mathrm{N}$ and $\mathrm{P}$ composition of Gloeotrichia pisum tissues $(\mathrm{N}=10)$ and of Vallisneria americana ( $\mathrm{Va})$ tissues free of $(\mathrm{N}=49)$ and colonized by $(\mathrm{N}=10)$ epiphytic G. pisum. For each variable, the probability (p) of significant difference between classes is as follows: $\% \mathrm{C}(\mathrm{p}=$ $0.06), \% \mathrm{~N}(\mathrm{p}<0.00001), \% \mathrm{P}(\mathrm{p}<0.00001)$; abundance groups for which means differ significantly are identified by different letters (Kruskal-Wallis ANOVA rank test). For each box plot, the boundary of the box indicates the 25th and 75th percentiles, the line within the box marks the median, whiskers above and below the box indicate the 10th and 90th percentiles and dots indicate the 5th and 95th percentiles

effect of the biomass of G. pisum was accounted for, the concentration of the different forms of $\mathrm{N}$ in water explained $40 \%$ of the variance in \% $\mathrm{N}$ in $\mathrm{V}$. americana $(\mathrm{p}<0.0001)$. The explanatory power of the relationship remained very highly significant and still explained $35 \%$ of the variance in $\% \mathrm{~N}$ in $V$. americana when calculations were made using DIN alone, after removing the effect of G. pisum. Conversely, after accounting for the effect of $\mathrm{N}$ forms, the biomass of $G$. pisum only explained $8 \%$ of the variance in $\% \mathrm{~N}$ in $V$. americana $(\mathrm{p}<0.01)$.

The stable isotopic signature of Gloeotrichia pisum was markedly different from that of the other primary producers collected at the same sites (Fig. 9). $\delta^{15} \mathrm{~N}$ values ranged from -5.9 to $-6.5 \%$ in macrophytes, filamentous cyanobacteria ( $L$. wollei) and chlorophytes (Hydrodictyon sp.). In contrast, the $\delta^{15} \mathrm{~N}$ signature of $G$. pisum was close to $0 \%(-0.08 \pm 1.15 \%$ [SD]), indicating the use of atmospheric N. The $\delta^{13} \mathrm{C}$ signature of $G$. pisum $(-13.0 \pm 3.7 \%)$ was less negative than that

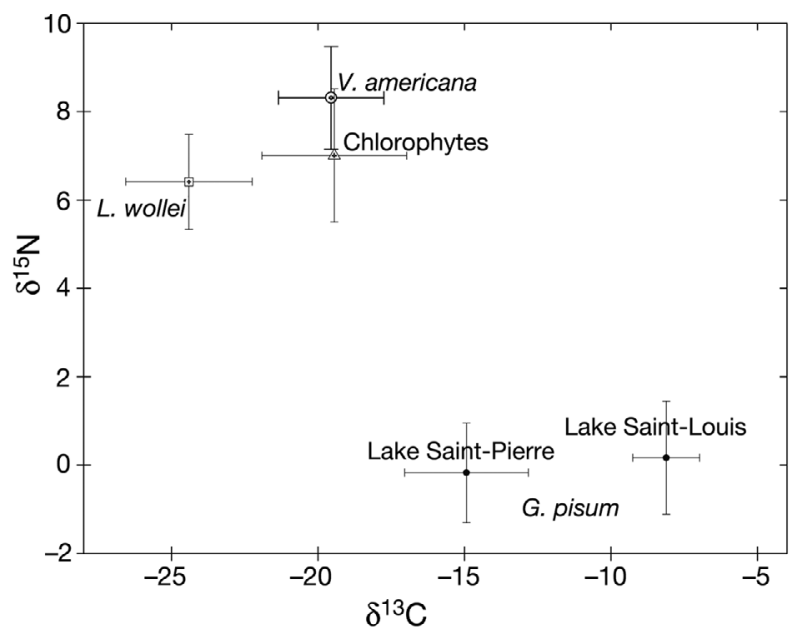

Fig. 9. Mean $( \pm \mathrm{SD}) \delta^{13} \mathrm{C}$ and $\delta^{15} \mathrm{~N}$ signatures for various primary producers in the St. Lawrence River. The isotopic signatures of Gloeotrichia pisum collected in late summer in Lake Saint-Louis ( $\mathrm{N}=6,2007$ only) and Lake Saint-Pierre $(\mathrm{N}=15,2006-2007)$ are shown separately. The isotopic signatures of other primary producers of the southern Lake SaintPierre stations are shown for the same period in 2006-2007: leaves of Vallisneria americana $(\mathrm{N}=19)$, filamentous chlorophytes $(\mathrm{N}=10)$, filamentous cyanobacteria $(L$. wollei, $\mathrm{N}=15)$

observed in the other types of vegetation (mean ranging from -25 to $-17 \%$ ). The $\delta^{15} \mathrm{~N}$ signature of G. pisum was equally low for both lakes, although $\delta^{13} \mathrm{C}$ isotopic signatures differed slightly among fluvial lakes.

\section{DISCUSSION}

\section{Spatial and temporal patterns of G. pisum occurrence}

Gloeotrichia pisum consistently occurred at shallow, clear-water sites ( $>24 \%$ of incident light reaching the bottom) characterized by moderate TDP (10 to $20 \mu \mathrm{g}$ P $\left.\mathrm{l}^{-1}\right)$ and low DIN $\left(<40 \mu \mathrm{g} \mathrm{N} \mathrm{l}^{-1}\right)$ concentrations. This pattern was confirmed for 2 summers in 2 fluvial lakes of the St. Lawrence River.

The seasonal occurrence of Gloeotrichia pisum also followed a clear pattern. Early colonization was observed in 2007 due to the combined effects of warm, sunny weather and low water levels recorded in early summer, leading to warm water temperatures and high bottom light intensity. The affinity of cyanobacteria to warm $\left(>15^{\circ} \mathrm{C}\right)$ water temperatures is well documented (Konopka \& Brock 1978, Robarts \& Zohary 1987). In 2007, low (drop of $>30 \mathrm{~cm}$ ) summer water levels resulted in longer water residence times and earlier onset of low DIN concentrations. For both 2006 and 2007, a 25 to 28 d lag was observed between the onset 
of low DIN and the first occurrence of G. pisum, consistent with the 25 to $36 \mathrm{~d}$ lag required for germination and pelagic recruitment of $G$. echinulata (Roelofs \& Oglesby 1970, Carey et al. 2008). This coincidence suggests that the development time of $G$. pisum may be similar to that of the better studied planktonic taxon. Whereas these conditions favoured G. pisum growth, the low water levels of 2007 coincided with a sharp decrease in \% $\mathrm{N}$ in Vallisneria americana tissues. Both the occurrence of $G$. pisum and the low condition of $V$. americana resulted from the occurrence of low DIN concentrations over the weeks prior to sampling, thus suggesting that the presence of G. pisum integrates temporally variable seasonal conditions.

\section{Linkage with hydrology}

The strong linkages between hydrology, nutrient concentration and algal species composition were highlighted by the fine-scale gradients along the south shore of Lake Saint-Pierre, where nutrient-rich waters originating from the tributaries travelled through a shallow macrophyte bed. In the upstream part of the gradient, water showed high DIN and TDP concentrations, coinciding with dense macrophytes, abundant filamentous chlorophytes and epiphytes, and the absence of Gloeotrichia pisum. Downstream of the dense macrophyte bed, TDP concentrations remained fairly constant but DIN concentrations and the biomass of primary producers dropped substantially, coincident with the presence of G. pisum. Similar nutrient gradients (particularly DIN) were documented across wetlands (Scott et al. 2005) and areas of the Florida Everglades (Vaithiyanathan \& Richardson 1999); such gradients may have resulted from plant assimilation and bacterial denitrification (Seitzinger et al. 2006). In contrast, TDP is constantly remineralized through plant assimilation and degradation (Rooney \& Kalff 2003) and thus remained fairly stable (>20 $\left.\mu \mathrm{g} \mathrm{P} \mathrm{l}^{-1}\right)$.

The development of DIN-depleted waters in shallow areas of the St. Lawrence River fluvial lakes (Hudon \& Carignan 2008) coincided with a shift from filamentous chlorophytes to cyanobacteria (Vis et al. 2007). Conversely, shifts from cyanobacterial to chlorophyte dominance were observed in shallow eutrophic lakes when concentrations of both $\mathrm{P}$ and $\mathrm{N}$ became excessive (Leonardson \& Ripl 1980, Jensen et al. 1994).

\section{Conditions affecting $G$. pisum occurrence}

As previously shown for the planktonic Gloeotrichia echinulata (Vuorio et al. 2006), a $\delta^{15} \mathrm{~N}$ signature consistently close to $0 \%$ o confirmed the reliance of epiphytic
G. pisum on atmospheric $\mathrm{N}$ in all the areas we surveyed in the St. Lawrence River. The ${ }^{13} \mathrm{C}$ enrichment exhibited both by epiphytic G. pisum and planktonic G. echinulata likely resulted from diffusion limitation due to the large colony size of these morphologically similar taxa (Vuorio et al. 2009). High illumination and adequate $\mathrm{P}$ concentrations are also required to sustain the extra energetic demand of atmospheric $\mathrm{N}_{2}$ fixation (Liao \& Lean 1978, Lundgren 1978). G. pisum was associated with clear waters in which TDP concentrations always exceeded $10 \mu \mathrm{g} \mathrm{P} \mathrm{l}^{-1}$. The water DIN:TDP molar ratios observed in the presence of $G$. pisum were extremely low $(\leq 5)$, and well below the Redfield ratio (16), indicating strong N limitation. Similar TDP concentrations and DIN:TDP ratios sustained diazotrophic planktonic cyanobacterial dominance in a wholeecosystem manipulation of a boreal shield lake (Schindler et al. 2008).

\section{Effects of low DIN on other primary producers}

Areas where Gloeotrichia pisum thrived also showed increasing biomass of another benthic cyanobacterium, Lyngbya wollei, which formed cm-thick mats of filaments at the sediment-water interface. Anoxic conditions under these mats could increase $\mathrm{P}$ availability from superficial sediment and allow $\mathrm{N}_{2}$ fixation by filaments close to the sediment. In contrast, algae such as epiphytic diatoms and filamentous chlorophytes, which rely on DIN as a N source, were disadvantaged, as evidenced by their sharp decrease in biomass in areas where G. pisum and L. wollei occurred. In addition, eukaryotes have a lower tolerance to anoxic waters that are potentially rich in sulfides than cyanobacteria (Camacho et al. 1996).

Similarly, rooted vascular macrophytes are tightly constrained in slow-flowing waters since they lack the ability to fix atmospheric $\mathrm{N}_{2}$ and thus derive most of their nutrients from the sediment (Carignan \& Kalff 1980). Such a disadvantage is exemplified by the $50 \%$ reduction in macrophyte biomass at stations where Gloeotrichia pisum occurred as well as the poor condition of Vallisneria americana, as shown by the low $\mathrm{N}$ and chl a content in its tissues. A partial correlation analysis suggested that $V$. americana's poor condition was more likely related to low DIN concentrations than to any direct effect of heavy colonization by G. pisum. Since $V$. americana does not make use of the DIN in water, its low condition likely resulted from low $\mathrm{N}$ content in the underlying sediments, which happens to coincide with low DIN concentration in water after its slow flow through dense macrophyte beds; whereas the former is induced by sedimentation upstream, the latter results from bacterial denitrification and algal 
assimilation. For example, the sandy sediments of areas with persistently low DIN concentrations where G. pisum occurred in Lake Saint-Pierre contained very low $\% \mathrm{C}(0.45 \pm 0.20 \%[\mathrm{SD}], \mathrm{N}=12)$ and $\% \mathrm{~N}$ $(0.02 \pm 0.01 \%[\mathrm{SD}], \mathrm{N}=12)$, but slightly higher \%P $(0.04 \pm 0.02 \%$ [SD], $\mathrm{N}=12)$ (C. Hudon unpubl. data). The low molar N:P ratio $(0.90 \pm 0.65$ [SD], $\mathrm{N}=12)$ supplied by the sediment was indicative of acute $\mathrm{N}$ limitation to vascular macrophytes (Duarte 1992).

The divergent responses of Vallisneria americana and Gloeotrichia pisum to N depletion are clearly indicated by their tissue chemical compositions. The cyanobacterial epiphyte harboured substantially higher $\% \mathrm{~N}$ than its macrophyte substratum, likely due to its diazotrophic ability. Despite G. pisum's high N content, the organic $\mathrm{N}$ incorporated into the macrophyte biomass was much greater on an areal basis than that incorporated in the epiphytic cyanobacteria. On average, $V$. americana and $G$. pisum contributed 2.0 (range: $0.02-2.4, \mathrm{~N}=122)$ and $0.1(0.002-0.4, \mathrm{~N}=17) \mathrm{g}$ $\mathrm{N} \mathrm{m}^{-2}$, respectively, to the littoral zone of Lakes SaintLouis and Saint-Pierre. Given a DIN-depleted zone of $\sim 25 \mathrm{~km}^{2}$ in southern Lake Saint-Pierre, the annual contribution of $V$. americana and $G$. pisum would translate to 50 and 2.5 tons of organic $\mathrm{N} \mathrm{yr}^{-1}$, respectively, which together represent $<1 \%$ of the annual load of organic $\mathrm{N}$ into the study area by the 3 largest southern tributaries of the St. Lawrence River (Hudon \& Carignan 2008). Although the contribution of G. pisum to the overall St. Lawrence River N budget is small, it could represent significant inputs locally, especially in $\mathrm{N}$ depleted southeastern Lake Saint-Pierre.

\section{CONCLUSION}

As shown by the high concordance between our field and laboratory observations, the presence/absence of Gloeotrichia pisum could be reliably determined in the field. The clear association of this taxon with areas of low DIN further made it a quick and easy indicator of late-summer nutrient concentrations. Our model predicted the presence/absence of $G$. pisum from DIN and TDP measurements in water with an $80 \%$ success rate, with similarly good performance using an independent validation data set.

The ecological niche of Gloeotrichia pisum might be broadly defined by its ability to grow under combinations of dissolved nutrient concentrations (e.g. low DIN and moderate TDP or adequate DIN and low TDP) that are unsuitable for other competing epiphytes which do not possess diazotrophic abilities. This study further supports the hypothesis that either $\mathrm{N}$ or P may limit (or co-limit) algal growth, depending on specific sets of environmental conditions (Lewis \& Wurtsbaugh 2008).
G. pisum integrates complex, temporally variable water-quality characteristics that are dependent upon hydrology and water residence time. This species thus appears to be an early warning indicator of chronic DIN depletion in aquatic environments, which is symptomatic of ongoing habitat degradation. In lakes and other water bodies with long residence times, such disequilibrium in dissolved $\mathrm{N}$ :P ratios in water could lead to planktonic blooms of diazotrophic cyanobacteria (Hyenstrand et al. 1998, Schindler et al. 2008). Similarly, in slow-flowing rivers such as the St. Lawrence River fluvial lakes, DIN depletion leads to widespread occurrence of benthic cyanobacteria, including $G$. pisum and mats of Lyngbya wollei (Vis et al. 2008). In addition to the potential production of cyanobacterial toxins and taste and odour compounds (Paerl 1988), DIN depletion coincides with a decline in the biomass and condition of submerged aquatic macrophytes. Given the importance of aquatic vegetation as habitats for invertebrates and fish (Tessier et al. 2008), its decrease and possible demise could signal a major reduction in the support capacity of St. Lawrence River fluvial lakes for secondary production.

Acknowledgements. J.-P. Amyot, J. Bernier, C. Boyko, R. Gladu, B. Gray, L. Gualtieri, P. Ho, N. Langlois, D. Lévesque, A.-M. Tourville, S. Trépanier and D. Walsh contributed to the field and laboratory work. We thank Hatch Laboratory (University of Ottawa) for carrying out isotopic analyses. Analyses of water chemistry and nutrient contents in plant tissues were carried out by the staff of the Quebec Laboratory for Environmental Testing (QLET) (Environment Canada), K. BonguéBoma and the laboratory staff of R. Carignan (Université de Montréal). Maps were drawn by F. Boudreault. We also thank P. Potvin for editorial comments. Two anonymous reviewers provided useful comments on an earlier version of the manuscript. This work was funded by the Natural Science and Engineering Research Council (Discovery Grant to A.C.) and Environment Canada under the St. Lawrence Action Plan (C.H.).

\section{LITERATURE CITED}

APHA (American Public Health Association) (1995) Standard methods for the analysis of water and wastewater, 19th edn. APHA, AWWA (American Water Works Association) and WEF (Water Environment Federation), Washington, $\mathrm{DC}$

Aziz A, Whitton BA (1988) Influence of light flux on nitrogenase activity of the deepwater rice-field cyanobacterium (blue-green alga) Gloeotrichia pisum in field and laboratory. Microbios 53:7-19

Camacho A, Garcia-Pichel F, Vicente E, Castenholz RW (1996) Adaptation to sulfide and to the underwater light field in three cyanobacterial isolates from Lake Arcas (Spain). FEMS Microbiol Ecol 21:293-301

Carey CC, Weathers KC, Cottingham KL (2008) Gloeotrichia echinulata blooms in an oligotrophic lake: helpful insights from eutrophic lakes. J Plankton Res 30:893-904

Carignan R, Kalff J (1980) Phosphorus sources for aquatic weeds: water or sediments? Science 207:987-989 
Chêtelat J, Pick FR (2001) Temporal variability of water chemistry in flowing waters of the northeastern United States: does river size matter? J N Am Benthol Soc 20:331-346

DFO (Department of Fisheries and Oceans Canada) (2007) Water level data at Lake Saint-Pierre (Courbe No. 2, gauging station 15975), 1961-2007 MEDS (Marine Environment Data Services). Government of Canada, Ottawa

Duarte CM (1992) Nutrient concentration of aquatic plants: patterns across species. Limnol Oceanogr 37:883-889

Environment Canada (2005) Manuel des méthodes d'analyses (annexe B). Environment Canada, Quebec Region, Scientific and Technical Services Section, Montreal

Environment Canada (2007) Daily air temperature data for 2006-2007, Dorval (Montreal's)-Pierre-Elliott Trudeau International airport) Weather Station (No. 7025250). Canadian Meteorological Service, Environment Canada, Montreal

Granetti G (1969) La Gloeotrichia pisum Thuret nel Lago Trasimeno. Riv Idrobiol 8:3-15

Howarth RW, Marino R (2006) Nitrogen as the limiting nutrient for eutrophication in coastal marine ecosystems: evolving views over three decades. Limnol Oceanogr 51: $364-376$

Hudon C, Carignan R (2008) Cumulative impacts of hydrology and human activities on water quality in the St. Lawrence River (Lake Saint-Pierre, Quebec, Canada). Can J Fish Aquat Sci 65:1165-1180

Hudon C, Lalonde S (1998) Biomasse et concentration en métaux des plantes aquatiques du Saint-Laurent (1993-1996). Scientific and Technical Report ST-174. Environment Canada, Montreal

Hyenstrand P, Blomqvist P, Pettersson A (1998) Factors determining cyanobacterial success in aquatic systems: a literature review. Arch Hydrobiol Spec Issues Adv Limnol 51: 41-62

> Jensen JP, Jeppesen E, Olrik K, Kristensen P (1994) Impact of nutrient and physical factors on the shift from cyanobacterial to chlorophyte dominance in shallow Danish lakes. Can J Fish Aquat Sci 51:1692-1699

Konopka A, Brock TD (1978) Effect of temperature on bluegreen algae (Cyanobacteria) in Lake Mendota. Appl Environ Microbiol 36:572-576

Leonardson L, Ripl W (1980) Control of undesirable algae and induction of algal succession in hypereutrophic lake ecosystems. In: Barica J, Mur LR (eds) Development in hydrobiology. Dr. W. Junk Publishers, The Hague, p 57-65

Lewis WM, Wurtsbaugh WA (2008) Control of lacustrine phytoplankton by nutrients: erosion of the phosphorus paradigm. Int Rev Hydrobiol 93:446-465

Liao CFH, Lean DRS (1978) Nitrogen transformation within the trophogenic zone of lakes. Can J Fish Aquat Sci 35: 1095-1101

Lundgren A (1978) Nitrogen fixation induced by phosphorus fertilization of a subarctic lake. In: Granhall U (ed) Environmental role of nitrogen fixing blue-green algae and asymbiotic bacteria. Swedish National Science Council, Stockholm, p 52-59

Nusch EA (1980) Comparison of different methods for chlorophyll and phaeopigment determination. Arch Hydrobiol Beih Ergeb Limnol 14:14-36

Editorial responsibility: Douglas Capone, Los Angeles, California, USA
Paerl HW (1988) Nuisance phytoplankton blooms in coastal, estuarine and inland waters. Limnol Oceanogr 33:823-847

Robarts RD, Zohary T (1987) Temperature effects on photosynthetic capacity, respiration, and growth rates of bloomforming cyanobacteria. N Z J Mar Freshw Res 21:391-399

Roelofs TD, Oglesby RT (1970) Ecological observation on the planktonic cyanophyte Gloeotrichia echinulata. Limnol Oceanogr 15:224-229

Rooney N, Kalff J (2003) Submerged macrophyte-bed effects on water-column phosphorus, chlorophyll a, and bacterial production. Ecosystems (N Y, Print) 6:797-807

Schindler DW (1974) Eutrophication and recovery in experimental lakes: implications for lake management. Science 184:897-899

Schindler DW, Hecky RE, Findlay DL, Stainton MP and others (2008) Eutrophication of lakes cannot be controlled by reducing nitrogen input: results of a 37-year wholeecosystem experiment. Proc Natl Acad Sci USA 105: $11254-11258$

Scott JT, Doyle RD, Filstrup CT (2005) Periphyton nutrient limitation and nitrogen fixation potential along a wetland nutrient-depletion gradient. Wetlands 25:439-448

Seitzinger S, Harrison JA, Böhlke JK, Bouwman AF and others (2006) Denitrification across landscapes and waterscapes: a synthesis. Ecol Appl 16:2064-2090

Stainton MP, Capel MJ, Armstrong FAJ (1977) The chemical analysis of fresh water, 2nd edn. Can Fish Mar Serv Misc Spec Publ 25:1-166

Tessier C, Cattaneo A, Pinel-Alloul B, Hudon C, Borcard D (2008) Invertebrate communities and epiphytic biomass associated with metaphyton and emergent and submerged macrophytes in a large river. Aquat Sci 70:10-20

Vaithiyanathan P, Richardson CJ (1999) Macrophyte species changes in the Everglades: examination along a eutrophication gradient. J Environ Qual 28:1347-1358

> Vis C, Hudon C, Carignan R, Gagnon P (2007) Spatial analysis of production by macrophytes, phytoplankton and epiphyton in a large river system under different water-level conditions. Ecosystems (N Y, Print) 10:293-310

Vis C, Cattaneo A, Hudon C (2008) Shift from chlorophytes to cyanobacteria in benthic macroalgae along a gradient of nitrate depletion. J Phycol 44:38-44

Vollenweider RA (1968) Scientific fundamentals of the eutrophication of lakes and flowing waters, with particular reference to nitrogen and phosphorus as factors in eutrophication. Tech Rep DAS/CS/68.27. OECD, Paris

> Vuorio K, Meili M, Sarvala J (2006) Taxon-specific variation in the stable isotopic signatures $\left(\delta^{13} \mathrm{C}\right.$ and $\left.\delta^{15} \mathrm{~N}\right)$ of lake phytoplankton. Freshw Biol 51:807-822

Vuorio K, Meili M, Sarvala J (2009) Natural isotopic composition of carbon $\left(\delta^{13} \mathrm{C}\right)$ correlates with colony size in the planktonic cyanobacterium Gloeotrichia echinulata. Limnol Oceanogr 54:925-929

Weyhenmeyer GA, Jeppesen E, Adrian R, Arvola L and others (2007) Nitrate-depleted conditions on the increase in shallow northern European lakes. Limnol Oceanogr 52: 1346-1353

Yin Y, Winkelman JS, Langrehr HA (2000) Long term resource monitoring program procedures: aquatic vegetation monitoring. LTRMP 95-P002-7, US Geological Survey, La Crosse, WI

Submitted: November 27, 2008; Accepted: June 18, 2009

Proofs received from author(s): September 23, 2009 